\title{
IAMJ
}

INTERNATIONAL

AYURVEDIC

MEDICAL JOURNAL

\section{THE ROLE OF SHATKRIYAKALA IN THE MANIFESTATION OF DISEASES}

\author{
$\underline{\text { Namrata Sahu}}^{1}, \underline{\text { Harsh Kumar }}^{2}, \underline{\text { Vinay Bhardwaj }}^{3}$ Gitanjali Sasmal $^{4}$ \\ ${ }^{1}$ PG Scholar Dept. of Kriyasharira, \\ ${ }^{2}$ PG Scholar, Dept. of Dravyaguna, \\ ${ }^{3}$ Lecturer Dept. of Kriyasharira, \\ ${ }^{4}$ Reader \& HOD Dept. of Kriyasharira. \\ Shri NPA Govt Ayurved College, Raipur, C.G., India
}

Corresponding Author: namratasahu601@gmail.com

https://doi.org/10.46607/iamj3609102021

(Published Online: October 2021)

Open Access

(C) International Ayurvedic Medical Journal, India 2021

Article Received: 29/09//2021 - Peer Reviewed: 07/10/2021 - Accepted for Publication: 08/10/2021

\section{Check for updates}

\section{ABSTRACT}

Ayurveda is the ancient system of medicine, preaches us many unique concepts. Shatkriyakala is one of them. Kriyakala is one of the varied important concepts described in Ayurveda treatises. Kriyakala means Goodtime or chance to administer treatment. These are six in number and are hence referred to as Shatkriyakala viz. Sanchaya, Prakopa, Prasara, Sthansamshraya, Vyakti and Bheda. It is an idea that describes different phases of a disease in its unique way. It shows the stepwise progression of Dosha and Rogas. Kriyakala is useful within the diagnosis, prognosis and therefore the treatment of a disease. This very concept is beneficial even in the prevention of diseases. Initial diagnosis of Rogas helps to cure the Rogas successfully without much discomfort in planning therapy. So, through this article, we have attempted to highlight the role of Shatakriyakala in clinical practice.

Keywords: Shatkriyakala, Dosha, Sanchaya, Prakopa, Prasara, Sthanasamshraya, Vyaktavastha, Bhedavastha, Roga, Nidana, Upadrava. 


\section{INTRODUCTION}

Ayurveda focuses its attention on holistic treatment. It follows a twofold method of treatment, which is preventive and curative. Which priory insists upon the prevention of the diseases rather than curative. The concept of Shatkriyakala is an objective approach of Ayurveda that gives an idea about the consecutive stages of the disease and accordingly preventive measures can be described to overcome complications. Early diagnosis of a disease in its growing stage can help a physician to require reformative action and reverse the imbalances at an initial stage of development, so preventing the emergence of the full-blown disease. If the physician is ready to detect the changes in early stages like Sanchaya (accumulation), Prakop etc. based on the manifestation of Dosha symptomatology and advise the techniques at that stage to stop further stages, so that disease might not become stronger. By knowing Shatkriyakala the physician can give the treatment to a weakened area or organ so that further Sthansamshrayavastha are often prevented. This concept is extremely useful in clinical practices which give the clear guideline that if Doshas are elevated within the initial stage i.e., Sanchaya-Avastha, they are doing not progressing further stages of the disease.

Shatkriya Kala - The term Shatkriya Kala comprises of three terms-

- Shat means six

- Kriya means action or treatment

- Kala means time or period

Now, summing up the three terms- Shatkriyakala means "Appropriate period to take action or implement treatment" Thus, Shatkriyakala refers to the recognition of the stage of a disease's progress, which helps to work out appropriate measures to correct the imbalance in Doshas. Acharya Sushruta, in his clinical text "Sushruta Samhita", has described the concept of Kriyakala as per the six stages which are

1) Sanchaya (Stage of accumulation)

2) Prakopa (Stage of aggravation)

3) Prasara (Stage of spread)

4) Sthanasamsraya (Stage of localization)
5) Vyakti (Stage of manifestation)

6) Bheda (Stage of differentiation).

In the process of disease manifestation, the shifting of morbid Dosha into the subsequent stage depends upon the potency of Nidana. The Nidana of Rogas is attributed to Dosha hence it is essential to know the status of Dosha in the form of Sanchaya or Prakopa as well as stage of progression at a given point a time. From the stage of Sanchaya to Prasara, the varied stages of the vitiation of Doshas are discussed and from Sthana-samshraya to Bheda types, different stages of disease progression are described.

1) Sanchaya (Stage of accumulation) ${ }^{1}$ - It is the first stage of Kriyakala. Sanchaya means collection or putting together. Thus, it is the inceptive stage of Kriyakala where the accumulation of Doshas due to various Nidana factors takes place. Doshas get accumulated in this stage, but they do not leave their place. Doshas manifest certain symptoms which are as follows: -

- Vata Sanchaya Lakshanas - Stabdhapoorna koshtata (Stiffness and fullness in the abdomen)

- Pitta Sanchaya Lakshanas - Pitavabhasata (Yellowishness of the body parts), Manda- ushanta (Mild increase in body temperature)

- Kapha Sanchaya Lakshanas - Angagaurava (Heaviness in the whole body), Alasya (Lassitude).

2) Prakopa (Stage of spread) ${ }^{2}$ - It is the second stage for preventive measures. If Doshas are in Sanchaya condition, along with the persistence of Nidanas, Dosha Prakopa stage follows. It is a phase wherein accumulated and stagnated Dosha move to other sites other than its main site.

- Vata Prakopa Lakshanas - Koshta- toda Sancharana (Pain and movement of Vata in Mahasrotasa)

- Pitta Prakopa Lakshana - Paridaha (Burning sensation all over the body), Pipasa (Excessive thirst), Amlika (sour eructation). Kapha Prakopa Lakshanas - Hridyotkledascha (excessive salvation in mouth), Annadwesha (aversion to food). 
Acharya Vagbhat $^{3}$ has described the stage of Prakopa as "Unmarga Gamita" i.e., inclination of Doshas to leave their original site. This stage has two types: -

- Sacahya Prakopa- This means a gradual increase of Doshas.

- Acahya Prakopa-Doshas pas directly to Prakopa stage without passing through Chaya Avastha.

3) Prasara (Stage of spread) ${ }^{4}$ - It is the third stage of Kriyakala. If Nidana Sevan is continued and Prakopavastha is not encountered, the Dosha will move to the stage of Prasara. In this stage, aggravated Doshas leave their original place and spread to the other parts of the body through Srotas just as the rice, flour and water when mixed and placed in a container grow up in quantity and overflows from the side of the vessel.

- Vata Prakopa Lakshana - Vimaraga Gamana (Regurgitation), Atopa (Flatulence).

- Pitta Prakopa Lakshana - Osha (sense of boiling), Chosha (Squeezing sense), Paridaha (Burning sensation), Dhoomayanani (Emitting smoke from the mouth).

- Kapha Prakopa lakshana - Arochaka (anorexia), Avipaka (dyspepsia), Chardi (vomiting), Angasada (lassitude).

4) Sthanasamsharaya (Stage of localization) $)^{5}$ - The fourth stage of Kriyakala is Sthanasamshraya. It is a prodromal phase wherein disease is yet to be manifested. If Nidana Sevan is continued in Prasara Avastha, Doshas move further into the stage of Sthanasamshraya. In this stage, vitiated Doshas in circulation settle wherever Srotakhavaigunya is present. The excited Dosha having extended to other parts of the body become localized and it marks the beginning of specific diseases about those Sthanas.

- When Doshas are localized in the abdomenGulma, Udara-Roga, Agnisada, Anaha, Visuchika, Atisara etc.

- When Doshas are localized in the urinary bladder- Prameha, suppression of urine and other urinary problems.

- When Doshas are localized in skin, muscle and blood-Minor skin diseases, leprosy, erysipelas.
- When Doshas are localized in Medas - Cysts, Scrofula, tumour, goitre, Alaji etc.

5) Vyakti (Stage of manifestation) ${ }^{6}$ - It is the fifth stage of Kriyakala. It is the stage where disease expresses itself. If Nidana persists, Dosha enters Vyaktibhava stage. This stage may be stated to be that of manifestation of the fully developed disease-Vyadhi Darshana i.e., appearance of all signs and symptoms of the disease is a result of this stage. The disease is well manifested in the form of fever, inflammation, tumour, cyst, abscess, erysipelas, diarrhoea etc.

6) Bheda (Stage of differentiation) ${ }^{7}$ - It is the sixth stage of Kriyakala. In this stage, specific signs, and symptoms of the diseases manifest. It is the stage in which the disease may become sub-acute and chronic or incurable. If the disease is untreated or improperly treated in Vyakti Avastha, then it leads to the succeeding stage of Bhedavastha where it gives birth to another disease or disease which are called Updrava. This stage is thought to be hardly curable, rather incurable eg) When an inflammatory condition is not treated properly in the beginning, it may form an abscess and finally, it may burst out and the permanent scar will remain at that place for the whole of the life. SIGNIFICANCE OF SHATAKRIYAKALA ${ }^{8}$ : -

1. Understand the stages in a definite sequence before the disease is diagnosed.

2. We can prevent the formation of disease if the initial stages are diagnosed correctly.

3. Different types of treatment can be given for different stages.

4. The physician can successfully cure the patient and prevent the recurrence of the disease.

\section{DISCUSSION}

Kriyakala means the good time or opportunity of treatment within the process of disease manifestation. It's useful to know the prognosis of the disease and in the decision of treatment strategy. While stating the significance of Shatkriyakala helps to cure the disease without much discomfort. Acharya Sushruta has stated that one who knows the accumulation, aggravation, spread, localization, manifestation, and 
specification of Doshas and their Upadrava (complication) is a good physician.

If we understand the Shatakriyakala properly the Nidana (pathology) are often be judged at its initial stage and treated easily. Thus, the knowledge of Shatakriyakala helps get the knowledge of the manifestation of various diseases and their Sadhyasadhyatva.

\section{CONCLUSION}

Shatkriyakala is an important concept in context to achieve the goal of Ayurveda. By gaining the knowledge of Shatkriyakala properly, the pathology is often arrested at the initial stage of the disease and thus it is often treated easily. It enables the treating physician to recognize the disturbances in their early formative stages and to enable to take necessary steps on time, to correct and eliminate the offending factors before they have caused sufficient damage. Knowledge of Shatakriyakala helps in understanding the process of manifestation of diseases as well as proper diagnosis of the diseases. The diagnosis of a disease and treatment properly according to Shatakriyakala are getting to become a successful or good physician. The knowledge of Shatakriyakala is useful for knowing the Sadhyaasadhyatva of Rogas and plays a crucial role within the treatment.

So, in the above literature, it is often concluded that the knowledge of Shatkriyakala helps in understanding the strategy of manifestation of various diseases.

\section{REFERENCES}

1. Sushruta Samhita text with English translation by Kaviraj Kunjalal Bhishagratna, Edited by Dr Laxmidhar Dwivedi, Chowkhamba Sanskrit Series, Varanasi 2005.

2. Sushruta Samhita text with English translation by Kaviraj Kunjalal Bhishagratna, Edited by Dr Laxmidhar Dwivedi, Chowkhamba Sanskrit Series, Varanasi 2005.

3. Sarth Vagbhat, Dr Ganesh Krishna Garde, Editor Reprint 2012, Prophishant Publishing house Pune 2012.

4. Sushruta Samhita text with English translation by Kaviraj Kunjalal Bhishagratna, Edited by Dr Lax- midhar Dwivedi, Chowkhamba Sanskrit Series, Varanasi 2005.

5. Sushruta Samhita text with English translation by Kaviraj Kunjalal Bhishagratna, Edited by Dr Laxmidhar Dwivedi, Chowkhamba Sanskrit Series, Varanasi 2005.

6. Sushruta Samhita text with English translation by Kaviraj Kunjalal Bhishagratna, Edited by Dr Laxmidhar Dwivedi, Chowkhamba Sanskrit Series, Varanasi 2005.

7. Sushruta Samhita text with English translation by Kaviraj Kunjalal Bhishagratna, Edited by Dr Laxmidhar Dwivedi, Chowkhamba Sanskrit Series, Varanasi 2005.

8. A textbook of Kriyasharira by Subhash Ranade, R.R. Deshpande, Swati Chobhe, Chowkhamba Sanskrit Pratishthan, Reprint;2018.

\section{Source of Support: Nil \\ Conflict of Interest: None Declared}

How to cite this URL: Namrata Sahu et al: The Role Of Shatkriyakala In The Manifestation Of Diseases. International Ayurvedic Medical Journal \{online\} 2021 \{cited October 2021\} Available from: http://www.iamj.in/posts/images/upload/2518_2521.pdf 